\title{
Viewpoint
}

\section{Regulatory and skills requirements for higher education in the Philippines}

\section{Kolawole Samuel Adeyemo}

\begin{abstract}
The provision of public resources to manage the expansion of the higher education system in the Philippines has been inadequate, and this has given rise to many private providers entering the HE domain. The proper regulation of higher education in the country is important if the Philippines is to respond to the challenge of producing the skills it needs for economic development. A Commission on Higher Education document of 2012 reiterated the mandate given to all higher education institutions in the Philippines to build a quality nation and to contribute to its global competitiveness. This mandate includes the need for the higher education system to produce graduates with analytical and problemsolving skills, among others. Perhaps the best one can hope for is that policies of this kind can provide an overarching framework and a general context for the development and strengthening of higher education institutions in order to make them relevant to the needs of the society in which they are situated.
\end{abstract}

Keywords: higher education policy; regulatory environment; Philippines; skills development

The author is with the Department of Education Management and Policy Studies, Faculty of Education, University of Pretoria, Groenkloof Campus, Pretoria 0002, South Africa. E-mail: samuel.adeyemo@up.ac.za.

With the dawn of the information age and the emergence of the global economy, higher education institutions (HEIs) are expected to produce graduates with relevant skills to operate effectively in this new world-wide environment. Post-secondary education is expected to prepare graduates with new skills, a broad knowledge base and a range of competencies for entry into a more complex and interdependent world. This has led to a situation in which quality assurance in higher education is becoming a top policy agenda in many nations (Altbach et al, 2009).
The global expansion of higher education over recent decades has moved up on government agendas as a result of drivers to develop a knowledge and skills-based economy. Similarly, attention should be paid to the category of skills needed to be produced by HEIs for the growth of the economy; the result could otherwise be more graduates with certain skills being produced than are needed. In ensuring that higher education delivers the high-quality, skilled graduates required by the economy, there is a need to put in place regulation whereby quality is ensured in the 
programmes offered by both public and private-sector higher education providers. In doing this, private providers need to be seen as also contributing to nation-building and to the social and economic needs of the country (Sirat, 2006). Both private and public higher education should be regulated to ensure that they play a complimentary role in responding to the needs of increased access to higher education and that quality education is provided by both sectors.

Higher education in the Philippines has experienced substantial growth and expansion over the last few decades. There has been a rise in the number of public and private universities and colleges offering a wide range of programmes - with a varying capacity to deliver teaching and learning services. As at 2014, Philippine higher education institutions have grown to a total number of 2,299 , of which $656(28.5 \%)$ are public and 1,643 $(71.5 \%)$ are private institutions, with a total student population of 3,563, 396 (CHED, 2014). The majority of the graduates are products of private institutions (CHED, 2014). The data therefore confirm that there is an expansion in higher education in the Philippines with private institutions contributing the higher percentages.

However, the expansion of HE in the Philippines has not been accompanied by the provision of adequate resources to produce highly-skilled Filipinos with critical thinking, problem-solving and decision-making capacities, communication skills and technical and social skills (see World Bank, 2012). These skills need to be produced by Philippines HEIs because they are not sufficiently available, at present, to meet global requirements. There is a continuous demand by industry for quality graduates with relevant skills and higher institutions have a responsibility to produce these graduates. This scenario highlights the importance of the relevance of curriculum content in those skills areas where the supply of graduates is insufficient to meet industry's needs. The dynamism of the demand for tertiary graduates in services emphasizes the importance of tailoring curriculum design and pedagogical approaches of tertiary education to labour-market needs.

The expansion in higher education in the Philippines has posed continuous challenges for HEIs regarding quality and the need for proper regulation. The proliferation of private higher education makes the problem of quality and quality assurance in need of even more urgent attention. The role of government regulatory bodies, in making sure that there is quality in its higher education system, is therefore critically important.

\section{Quality assurance and the need for regulation}

The pursuit of quality and quality assurance in the Philippine higher education system is in response to the need to be globally relevant in terms of skills needed in the workplace. A measurement of the quality of education that universities and colleges offer is the students' pass rate in the board examinations of the Professional Regulation Commission (PRC) across 40 professional fields. To ensure the proper regulation and quality of higher education, the Commission on Higher Education (CHED) has been mandated by law to implement policies and plans and oversee the affairs of all HEIs in the country. The CHED is also tasked with formulating policy to create an atmosphere conducive for the activities of private independent accrediting agencies working in quality assurance.

With regard to skills production, the CHED is required to regulate HEIs in order to ensure the production of graduates with high levels of academic thinking and behavioural and technical skills that are aligned with national and international academic and industry standards and needs (CHED, 2012). The CHED has produced guidelines for quality to ensure that every higher education institution complies with this mandate and as part of its efforts to foster a quality nation that is globally competitive.

The CHED has adopted a developmental approach to quality assurance in order to help all HEIs, both private and public, to develop a culture of quality so that they are able to deliver on the assigned mandate. For the CHED quality assurance means that HEIs should have mechanisms, procedures and processes in place to ensure that the desired quality is delivered in terms of constitutional mandates. For instance, in teacher education in particular, the CHED Memorandum No 30 (CHED, 2004) instructs HEIs to produce graduates with high levels of literacy, communication, numeracy, critical thinking and learning skills and with a deep and principled understanding of the learning processes. Similarly, teachers must understand their role in facilitating these processes and they should be able to apply a wide range of teaching process skills, including curriculum development, lesson planning, materials development, educational assessment and the use of a variety of teaching approaches; they must also be able to demonstrate knowledge of and the ability to meet professional and ethical requirements related to the teaching profession.

Teacher education is important, particularly in the production of skills needed by society. As such the quality of teachers is significant and related to skills 
development. However, the Professional Regulation Commission (PRC) report on the national Licensure Examination for Teachers (LET) shows that 25,301 of 70,786 elementary teacher examinees $(35.7 \%)$ and 26,767 of 77,803 secondary teacher examinees $(34.4 \%)$ successfully passed the LET in August 2014 in Hong Kong and 24 testing centres across the Philippines (PRC, 2014). However, the constant poor performance of graduates in different professional discipline examinations of the PRC is worrying, because it is a reflection of the state of higher education institutions in terms of 'quality'. It also reveals a gap between the expectations of government represented by the CHED and the needs of society in terms of quality and skills that need to be produced by the HEIs in teacher education.

The majority of Overseas Filipino Workers are employed in selected skills areas that do not require, among others, critical thinking, decision-making strengths and strong communication skills (see POEA, 2006). These skills, however, are critical to the Philippines as a nation. Perhaps it is the case that higher education institutions have been over-concentrating on offering programmes which have no relevance to the needs of the society but which are required for employment abroad and demanded by the students and, thus, failing the stated mandate. The relevant programmes for nation-building, such as engineering, health, medicine, law, science and agriculture are undersubscribed (see POEA, 2006), possibly due to high tuition costs, the challenge of providing adequate resources, and the challenges facing private institutions to deliver these skills. Public institutions that offer them have limited space and are also faced with budget constraints.

Industry needs graduates with relevant skills, knowledge and values to make a relevant contribution to society. Because the majority of the graduates from the Philippines are the product of private higher education, the questions 'Quality of what?' and 'How does the Philippines meet the increased demand for higher education without compromising the quality and skills needed to develop the society and the economy?' are raised. The need, therefore, is to regulate higher education properly in the Philippines, and private institutions in particular, is important in addressing the challenge of the production of skills that are relevant to the needs of the national economy. This paper, therefore, concludes with recommendations concerning the actions deemed necessary for improving the quality of higher education in the Philippines in order to bridge the gap between what employers and the nation needs and what higher education produces.

\section{Concluding remarks}

This paper reports on the growth of higher education in the Philippines and its effects on skills production. The Philippines has experienced significant expansion of $\mathrm{HE}$, taking the form of an increase in the number of higher education providers which included a rapid increase in the number of private HEIs. These developments were a response to the increase in demand for access to higher education in the Philippines which, with the proliferation of providers and institutional types, has given rise to the need to address problems of skills demands and skills gaps. It has been shown that the expansion of higher education in the Philippines has been accompanied by the emergence of problems of quality: failure to make more resources available has caused a fall in the quality of graduates needed for national development.

In considering the situation in the Philippines, the national government should realize that unless the higher education system is reformed the provision of relevant skills for developing the economy will be impossible. Private higher education in the Philippines can be reformed in order to address the skills crisis in the social and economic sectors. It should start by carefully defining what skills higher education needs to produce to meet the demands of society and the economy, what aspects of quality assurance criteria need to be refocused in order to reflect national needs with regard to skills in terms of output-based quality assurance practices, and how to incorporate these criteria into the evaluative measurement of the national quality assurance system, by benchmarking international practices and adapting them to the socio-politicaleconomic situation of the country. The ability to adapt policy to view private higher education as public, with regard to providing funding and grants and to the accreditation process, should be developed in order to yield better results. While the regulation of higher education should be strengthened in the Philippines, the overproduction of graduates with gaps in their skills is also an important concern.

In this context, it is interesting to note the case of South Africa, where a Government White Paper (Number 3) - released in 1997, three years after the attainment of democracy - regarded quality assurance as one of the paramount pursuits in the transformation of higher education. The approach adopted by the South African government was that there should be one regulatory framework for both public and private higher education institutions. All HEIs in the country, including foreign branches, are required to register their programmes with the South African Qualifications Authority, and to be quality assured (accreditation) by 
the Council on Higher Education. In addition, their curricula are required to have relevance to the South African context and meet its societal needs. The financial viability of private providers and quality teaching and learning were strictly examined and are continually monitored by the Department of Education. Quality measures and concerns were some of the considerations by the South African government in its proclamation of merger policy in 2002.

The case of South Africa provides significant evidence of the role of central government with regard to proper regulation and the impact of policy in achieving quality higher education. It is argued here, therefore, that the Philippines HE policy framework should be far more holistic. Policies should focus on specific and more practical issues with regard to their longer-term and wider relationships to the demands of national and international development.

\section{References}

Altbach, P.G., Reisberg, L., and Rumbley, L.E. (2009), 'Trends in global higher education: tracking an academic revolution', report prepared for the UNESCO 2009 World Conference on Higher Education, UNESCO, Paris, http://www.uis. unesco.org/Library/Documents/trends-global-highereducation-2009-world-conference-en.pdf (accessed 04 March 2015).
CHED (2004), 'Revised policies and standards for undergraduate teacher education curriculum', Memorandum Order No 30, http://www.ched.gov.ph//wp-content/uploads/ 2013/07/CMO-No.30-s2004.pdf (accessed 04 March 2015).

CHED (2012), 'Policy-standard to enhance quality assurance in Philippine higher Education through an outcomes-based and typology-based QA', CHED Memorandum Order No 46, http://www.ched.gov.ph/wp-content/uploads/2013/07/CMONo.46-s2012.pdf (accessed 04 March 2015).

CHED (2014), 'Higher education data: 2014 (public and private HEls)', http://www.ched.gov.ph/wp-content/uploads/2014/ temp/10-03/home/Higher\%20Education\%20 Data\% 202014\%20-\%20Public\%20and\%20Private\%20HEls.pdf (accessed 02 December 2014).

POEA (2006) Overseas Employment Statistics (2007-2011), Philippines Overseas Employment Administration, Department of Labour, Mandaluyong City, The Philippines, http://www.poea.gov.ph/stats/2011Stats.pdf (accessed 09 June 2012).

PRC (Professional Regulation Commission) (2014), PRC report, http://www.prc.gov.ph/news/?id=448 (accessed 26 November 2014).

Sirat, M. (2006), 'Malaysia', in Higher Education in South-East Asia, UNESCO Asia and Pacific Regional Bureau for Education, Bangkok, Thailand, http://unesdoc.unesco.org/ images/0014/001465/146541e.pdf (accessed 04 March 2015).

World Bank (2012), 'Putting higher education to work: skills and research for growth in East Asia', World Bank East Asia and Pacific Regional Report, World Bank, Washington DC, https://openknowledge.worldbank.org/handle/10986/2364 (accessed 04 March 2015). 